\title{
The Energy from Renewable Sources in the European Union: Achieving the Goals
}

\author{
Sorin Petrica Angheluta ${ }^{1}$, Sorin Burlacu ${ }^{1}$, Amelia Diaconu ${ }^{2}$ and \\ Cristina Stefania Curea ${ }^{1}$
}

\begin{abstract}
The existence and continuity of life on Earth is based on the existence of an ecological balance. Under the influence of pollution, the quality of the natural environment gradually degrades. Thus, pressures are exerted on the environment, including from energy production and consumption activities. The different phenomena of pollution, associated with the destruction of the environment, have made the sources of energy production diversified. Sustainable development can be achieved through the use of technologies that protect the environment. Within the electricity sector, energy from renewable sources has grown significantly in recent years. Energy production from Renewable energy reduces the use of fossil fuels, but also influences the process of reducing greenhouse gases. The article starts from the analysis of the current situation of renewable sources in the member countries of the European Union. With support of the comparative analysis of existing data at European level, the stage of achieving the European Union's objectives on renewable energy is presented. Also, comparative analyses of data on the share of renewable energy in final energy consumption are presented. Lack of emissions of pollutants, and the fact that they are inexhaustible, make, on the whole of electricity production, the share of renewable sources increases.
\end{abstract}

Keyword: Renewable energy, European Union, electricity production

\section{Introduction}

In some areas, heating needs can be met with renewable energy sources. The desire to increase consumer energy security has made the energy sector in most European countries turn (Litra, M., \& Burlacu, S., 2014).. These transformations included the field of renewable energy sources. An alternative to the use of fossil fuels is renewable energy sources. The use of renewable energy sources leads to the reduction of greenhouse gas emissions. Greenhouse gas concentrations are increasing both due to inappropriate land use and deforestation, as well as due to the use of fossil fuels. Plants, animals and humans are affected by environmental degradation. Economic activities generate pollution (Bran, F., Alpopi, C., \& Burlacu, S. ,2018).. Thus, pollutants influence the regeneration of ecosystems. The cycle of use of raw materials (manufacture of products, consumption of products, generation of waste) represents competition for natural resources. Thus, mitigating climate change and improving energy security can be based on the use of renewable energy sources.

Both local and regional small and medium-sized enterprises are believed to be able to contribute to economic growth and job creation by investing in renewable energy (Ionita, F., Ursacescu, M., \& Burlacu, S., 2009)..

At European level, a mandatory target for renewable energy has been set (Burlacu, S., Profiroiu, A., \& Vasilache, P. C., 2019).. Thus, renewable energy sources in the European 
Union should represent 20\% of energy consumption by 2020 (EP, 2009). This percentage is set to increase by 2030 . The share of renewable energy sources should reach at least $35 \%$ in final energy consumption by 2030, according to a resolution on renewable sources approved in early 2018 by to the European Parliament (EP, 2018). Also, for 2030 it is proposed that from the total energy consumption in transports, at least $12 \%$ should be renewable energy sources. It also proposes wider deployment of renewable energy in the heating and cooling sector.

\section{Literature Review}

The world population is on the rise. This also increases energy requirements. Using a high percentage of fossil fuels to produce electricity has led to exhaustion of fossil fuel reserves. At the same time, other negative aspects, such as fluctuations in fuel prices and greenhouse gas emissions have also emerged (Owusu, P.A., \& AsumaduSarkodie, S., 2016).

Thus, the lack of measures to reduce greenhouse gas emissions can turn climate change into irreversible threats to human communities (UNFCCC, 2015).

The use of renewable resources influences the environment by producing minimal secondary waste (Panwar, Kaushik \& Kothari, 2011).

Given the increase in the share of renewable resources in electricity generation, there is an increase in investment in renewable energy (Rezec \& Scholtens, 2017).

The share of renewable energies in European energy consumption has increased from $8.5 \%$ in 2004 to $17 \%$ in 2016. The European target for 2020 is $20 \%$. The use of renewable energy sources has made it possible to reduce greenhouse gas emissions. It can be appreciated that the aspects of energy supply and demand will be those that will affect the global balance of power (Paltsev, 2016).

In some areas of the world, renewable energy can solve the lack of energy, making it possible to reduce greenhouse gas emissions as well. However, the application of renewable technologies depends heavily on local conditions (Su, Kao \& Huang, 2012).

The dynamic trends of the global market have influenced decisions taken in the field of renewable energy. Thus, the use of renewable energy sources was based on some local advantages (Ćetković \& Buzogány, 2016).

In the decarbonisation of industrial processes, issues related to energy efficiency will be of great interest (Burlacu, S., Gutu, C., \& Matei, F. O. , 2018).. At present, 40\% of energy demand comes from buildings. Many of these buildings do not use renewable sources (Bran, F., Alpopi, C., \& Burlacu, S. , 2018).. To this end, it is necessary to use intelligent building management systems as well as improved insulating materials. An important role will be played by heating from renewable sustainable sources (EC, 2018).

Fossil fuels are the most used in today's energy systems. Renewable energy sources underpin the transition to clean energy.

Europe's greenhouse gas-free electricity production has grown in recent years, making it almost half the total electricity production.

Worldwide, 10 million employees work in 25 major renewable energy companies. Six of these enterprises (a total of about 1.5 million employees) are in the European Union (EC, 2018). It is hoped that the increase in the use of energy from renewable sources will 
be achieved with the help of local communities. At the same time, the flexibility of energy systems as well as their digitized management must be given special importance.

\section{Methodology of Research}

The transition to low-carbon energy systems offers the opportunity to reduce environmental pollution, stimulate new jobs and increase energy security (UNEP, 2011). The article starts from the analysis of the current situation of renewable sources in the member countries of the European Union. For the purpose of presenting the stage of achieving the European Union's objectives on renewable energy, the comparative analysis of existing data at European level was used. Also, comparative analyses of data on renewable energy sources in transport, electricity and heating and cooling are presented.

\section{Results and Discussions}

Globally, in order to achieve the goals agreed at the 2015 Climate Conference in Paris, energy changes are needed (UNFCCC 2015).

Efforts to reduce dependence on fossil fuels are an asset for renewable energy sources. Thus, the transition to clean energy is the replacement of fossil fuels with renewable energy sources.

Member States have introduced measures to increase the share of energy from renewable sources. National targets for renewable energy are also set for each country. Thus, we can track the outcome of applying these measures to achieve the goals. When setting these targets, the overall potential for renewable energy sources was taken into account. Thus, for the share of renewable energy in gross final energy consumption, of the data available on the EUROSTAT website corresponding to 2017, the following countries have reached and exceeded the 2020 target (in alphabetic order): Bulgaria, Czechia, Denmark, Estonia, Croatia, Italy, Lithuania, Hungary, Romania, Finland, Sweden.

Table 1: Share of renewable energy in gross final energy consumption (\%)

\begin{tabular}{|l|c|c|c|}
\hline Countries & $\mathbf{2 0 0 4}$ & $\mathbf{2 0 1 7}$ & Target 2020 \\
\hline European Union & 8.53 & 17.52 & 20 \\
\hline Austria & 22.66 & 32.56 & 34 \\
\hline Belgium & 1.89 & 9.06 & 13 \\
\hline Bulgaria & 9.45 & 18.73 & 16 \\
\hline Croatia & 23.41 & 27.28 & 20 \\
\hline Cyprus & 3.07 & 9.85 & 13 \\
\hline Czechia & 6.86 & 14.76 & 13 \\
\hline Denmark & 14.85 & 35.77 & 30 \\
\hline Estonia & 18.36 & 29.21 & 25 \\
\hline Finland & 29.23 & 41.01 & 38 \\
\hline France & 9.50 & 16.30 & 23 \\
\hline Germany & 6.18 & 15.45 & 18 \\
\hline Greece & 6.88 & 16.32 & 18 \\
\hline Hungary & 4.36 & 13.33 & 13 \\
\hline
\end{tabular}




\begin{tabular}{|l|c|c|c|}
\hline Countries & $\mathbf{2 0 0 4}$ & $\mathbf{2 0 1 7}$ & Target 2020 \\
\hline Ireland & 2.38 & 10.65 & 16 \\
\hline Italy & 6.32 & 18.27 & 17 \\
\hline Latvia & 32.79 & 39.01 & 40 \\
\hline Lithuania & 17.22 & 25.84 & 23 \\
\hline Luxembourg & 0.90 & 6.38 & 11 \\
\hline Malta & 0.10 & 7.17 & 10 \\
\hline Netherlands & 2.05 & 6.60 & 14 \\
\hline Poland & 6.91 & 10.90 & 15 \\
\hline Portugal & 19.21 & 28.12 & 31 \\
\hline Romania & 16.19 & 24.47 & 24 \\
\hline Slovakia & 6.39 & 11.49 & 14 \\
\hline Slovenia & 16.13 & 21.55 & 25 \\
\hline Spain & 8.33 & 17.51 & 20 \\
\hline Sweden & 38.67 & 54.50 & 49 \\
\hline United Kingdom & 1.13 & 10.21 & 15 \\
\hline
\end{tabular}

Source: own processing according to data published by Eurostat, 2019

Compared to 2004, in 2017 there are significant increases for Denmark $(+20.92 \%)$, Sweden $(+15.83 \%)$, Italy $(+11.95 \%)$, Finland (+11.78\% Estonia $(+10.85 \%)$.

In 2017, the highest values were recorded in Sweden (54.5\%), Finland (41.01\%), Latvia (39.01\%), Denmark (35.77\%), Austria (32.56\%), Estonia (29.21\%), Portugal (28.12\%), Croatia $(27.28 \%)$.

It is worth noting that in 2017, other European countries that are not in the European Union have high values: Iceland (71.57\%), Norway $(71.18 \%)$, Montenegro (40.03\%), Albania (34.57\%), Serbia (20.61\%).

It is desirable that energy-generating technologies are increasingly based on energy from all types of renewable sources.

Measures to reduce greenhouse gas emissions may also require energy consumption control and increased energy efficiency, and increase the use of energy from renewable sources.

The use of local energy sources allows for reduced transport distances and reduces energy transmission losses. These activities can lead to opportunities for new jobs, which means a positive impact on regional and local development opportunities.

Also, renewable energy can be used for centralized heating and cooling installations.

The following table shows the comparative situation of renewable energy sources in transport, in electricity and in heating and cooling, for 2004 and 2017.

Table 2: Share of renewable energy sources in transport, in electricity and in heating and cooling

\begin{tabular}{|l|c|c|c|c|c|c|}
\hline \multirow{2}{*}{ Countries } & \multicolumn{2}{|c|}{$\begin{array}{c}\text { Renewable energy } \\
\text { sources in transport }\end{array}$} & \multicolumn{2}{c|}{$\begin{array}{c}\text { Renewable energy } \\
\text { sources in electricity }\end{array}$} & $\begin{array}{c}\text { Renewable energy sources } \\
\text { in heating and cooling }\end{array}$ \\
\cline { 2 - 7 } & $\mathbf{2 0 0 4}$ & $\mathbf{2 0 1 7}$ & $\mathbf{2 0 0 4}$ & $\mathbf{2 0 1 7}$ & $\mathbf{2 0 0 4}$ & $\mathbf{2 0 1 7}$ \\
\hline EuropeanUnion & 1.39 & 7.56 & 14.30 & 30.75 & 10.40 & 19.48 \\
\hline Austria & 4.53 & 9.74 & 61.62 & 72.17 & 20.17 & 32.05 \\
\hline Belgium & 0.53 & 6.58 & 1.69 & 17.24 & 2.85 & 8.03 \\
\hline Bulgaria & 0.88 & 7.24 & 9.09 & 19.12 & 14.06 & 29.90 \\
\hline
\end{tabular}




\begin{tabular}{|l|c|c|c|c|c|c|}
\hline \multirow{2}{*}{ Countries } & \multicolumn{2}{|c|}{$\begin{array}{c}\text { Renewable energy } \\
\text { sources in transport }\end{array}$} & \multicolumn{2}{c|}{$\begin{array}{c}\text { Renewable energy } \\
\text { sources in electricity }\end{array}$} & $\begin{array}{c}\text { Renewable energy sources } \\
\text { in heating and cooling }\end{array}$ \\
\cline { 2 - 7 } & $\mathbf{2 0 0 4}$ & $\mathbf{2 0 1 7}$ & $\mathbf{2 0 0 4}$ & $\mathbf{2 0 1 7}$ & $\mathbf{2 0 0 4}$ & $\mathbf{2 0 1 7}$ \\
\hline Croatia & 0.99 & 1.18 & 35.03 & 46.42 & 29.44 & 36.55 \\
\hline Cyprus & 0 & 2.57 & 0.01 & 8.90 & 9.26 & 24.49 \\
\hline Czechia & 1.57 & 6.58 & 3.69 & 13.65 & 9.93 & 19.65 \\
\hline Denmark & 0.44 & 6.85 & 23.75 & 60.36 & 20.64 & 46.55 \\
\hline Estonia & 0.18 & 0.40 & 0.47 & 17.03 & 33.22 & 51.64 \\
\hline Finland & 1.01 & 18.83 & 26.71 & 35.22 & 39.50 & 54.85 \\
\hline France & 1.48 & 9.14 & 13.78 & 19.91 & 12.52 & 21.35 \\
\hline Germany & 2.21 & 7.03 & 9.37 & 34.41 & 7.15 & 13.42 \\
\hline Greece & 0.08 & 1.80 & 7.84 & 24.47 & 12.77 & 26.57 \\
\hline Hungary & 0.92 & 6.81 & 2.22 & 7.49 & 6.45 & 19.64 \\
\hline Ireland & 0.04 & 7.43 & 6.03 & 30.09 & 2.87 & 6.86 \\
\hline Italy & 1.21 & 6.48 & 16.09 & 34.10 & 5.71 & 20.08 \\
\hline Latvia & 2.14 & 2.54 & 45.96 & 54.36 & 42.49 & 54.58 \\
\hline Lithuania & 0.41 & 3.69 & 3.59 & 18.25 & 30.45 & 46.50 \\
\hline Luxembourg & 0.13 & 6.44 & 2.76 & 8.05 & 1.83 & 8.11 \\
\hline Malta & 0 & 6.80 & 0 & 6.58 & 1.04 & 19.83 \\
\hline Netherlands & 0.46 & 5.91 & 4.45 & 13.80 & 2.21 & 5.93 \\
\hline Poland & 1.44 & 4.20 & 2.21 & 13.09 & 10.21 & 14.48 \\
\hline Portugal & 0.42 & 7.93 & 27.39 & 54.17 & 32.50 & 34.39 \\
\hline Romania & 1.60 & 6.56 & 24.97 & 41.63 & 17.34 & 26.58 \\
\hline Slovakia & 1.46 & 7.03 & 15.40 & 21.34 & 5.06 & 9.84 \\
\hline Slovenia & 0.85 & 2.74 & 29.27 & 32.43 & 18.36 & 33.25 \\
\hline Spain & 1.03 & 5.92 & 18.98 & 36.34 & 9.50 & 17.52 \\
\hline Sweden & 6.29 & 38.63 & 51.18 & 65.89 & 46.63 & 69.07 \\
\hline UnitedKingdom & 0.35 & 5.05 & 3.53 & 28.11 & 0.73 & 7.45 \\
\hline Soure: awn & 0.06 & & & \\
\hline
\end{tabular}

Source: own processing according to data published by Eurostat, 2019

It is noted that for renewable energy in transport in 2017, the highest values were recorded in Sweden (38.63\%), Finland (18.83\%), Austria (9.74\%), France (9, 14\%), Portugal (7.93\%). Also, as compared to 2004, renewable energy sources in transport increased most in: Sweden $(+32.34 \%)$, Finland $(+17.82 \%)$, France $(+7.66 \%)$, Portugal $(+7.51 \%)$, Ireland $(+7.39 \%)$.

For renewable energy in electricity in 2017, the highest values were recorded in Austria (72.17\%), Sweden (65.89\%), Denmark (60.36\%), Latvia (54.36\%), Portugal (54.17\%), Croatia (46.42\%), Romania (41.63\%), Spain (36.34\%), Finland (35.22\%), Germany $(34.41 \%)$. In addition, compared to 2004, renewable energy sources in electricity increased most in: Denmark $(+36.61 \%)$, Portugal $(+26.78 \%)$, Germany $(+25.04 \%)$, United Kingdom $(+24.58 \%)$, Ireland $(+24.06 \%)$, Italy $(+18.01 \%)$, Spain $(+17.36 \%)$, Romania (+16.66\%), Greece $(+16.63 \%)$, Estonia $(+16.56 \%)$.

For renewable energy sources in heating and cooling in 2017, the highest values were recorded in Sweden (69.07\%), Finland (54.85\%), Latvia (54.58\%), Estonia (51.64\% \%), Denmark (46.55\%), Lithuania (46.5\%), Croatia (36.55\%). Also, compared to 2004, in 2017, renewable energy sources in heating and cooling increased most in: Denmark $(+25.91 \%)$, 
Sweden (+22.44\%), Malta (+18.79\%), Estonia (+18.42\%), Lithuania (+16.05\%), Bulgaria $(+15.84 \%)$, Finland (+15.35\%), Cyprus (+15.23\%), Slovenia (+14.89\%), Italia (+14.37\%). Taking into account the values registered in 2017, the following figure shows the evolution of renewable energy sources for the countries with the highest values.

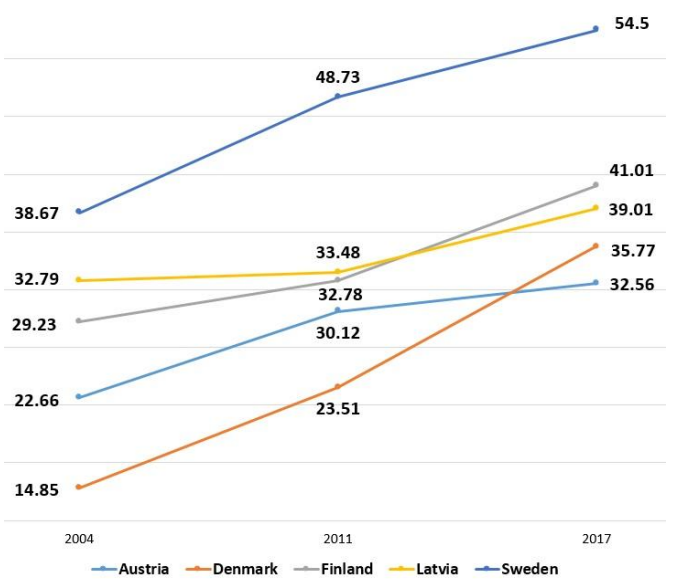

Figure 1 - The evolution of renewable energy sources (\%)

Source: own processing according to data published by Eurostat, 2019

It is noticed that Sweden had the highest values (38.67\% in 2004, 48.73\% in 2011 and $54.5 \%$ in 2017) throughout the analysed period (2004-2017).

On the basis of the high values recorded in 2017, we selected the five countries and the following figures show the comparative evolution of the other indicators.

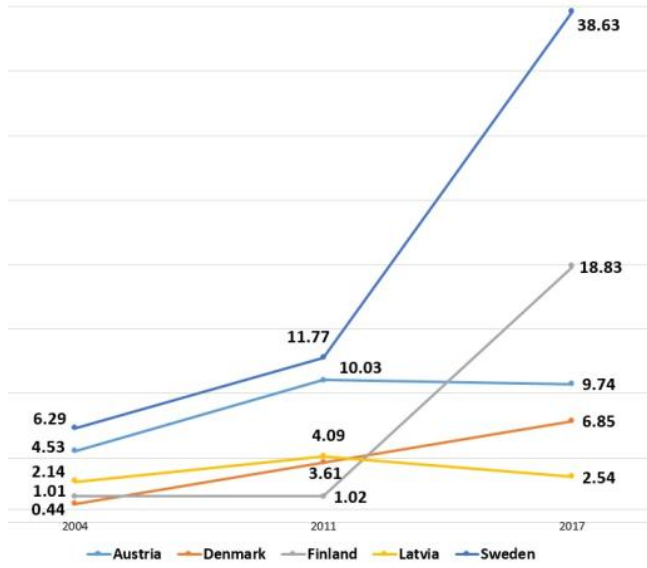

Figure 2 - The evolution of renewable energy sources in transport (\%)

Source: own processing according to data published by Eurostat, 2019

Thus, Figure 2 shows the evolution of renewable energy sources in transport. There are spectacular increases for Sweden and Finland, but also for Denmark. In Latvia and Austria, the trends are slightly downward. 
At European Union level, almost a quarter of greenhouse gas emissions are thought to be due to transport. For this reason, it is necessary to reduce the level of the gases emitted by vehicles. The benefits of such an intervention are major and relate to increasing the health of the population and cleaner air. Intelligent traffic management also enables the implementation of greener mobility. Carbon dioxide-free transport technologies will reduce atmospheric pollution and will also contribute to improving the quality of life (EC, 2018).

Figure 3 shows the evolution of renewable energy sources in electricity.

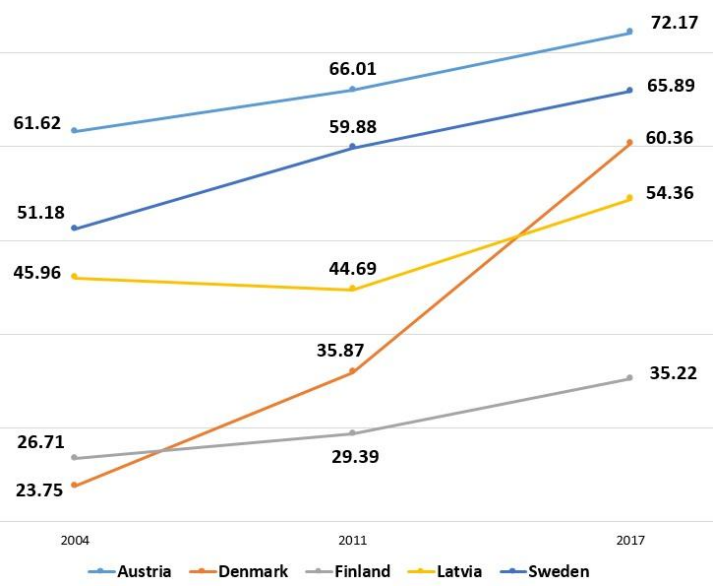

Figure 3 - The evolution of renewable energy sources in electricity (\%)

Source: own processing according to data published by Eurostat, 2019

For this indicator, trends are increasing for all 5 countries. The highest values were recorded in Austria (72.17\%) and Sweden (65.89\%). However, a significant increase is observed for Denmark.

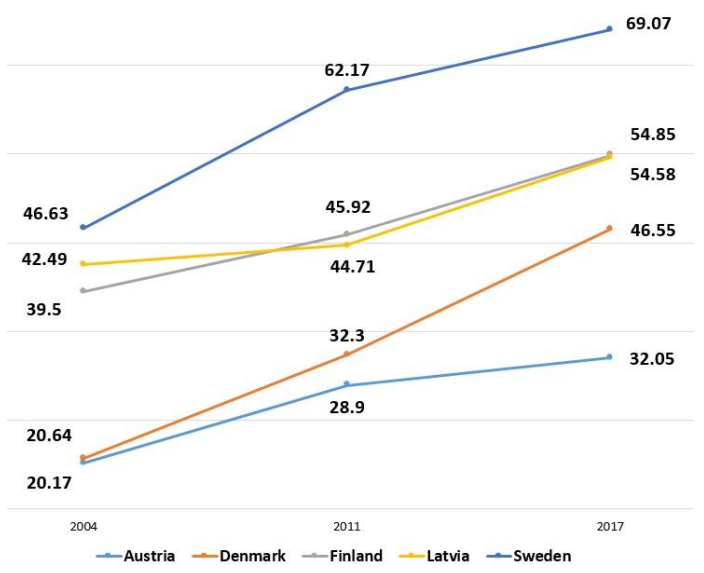

Figure 4 - The evolution of renewable energy sources in heating and cooling (\%)

Source: own processing according to data published by Eurostat, 2019 
Figure 4 presents the evolution of renewable energy sources in heating and cooling. Sweden has the highest values throughout the analysed period. The increasing trends observed in the other indicators are also preserved for this indicator. A particular increase is seen again for Denmark.

\section{Conclusions}

Human development can be achieved through the use of energy. Considering climate change, we can see that the energy needs of future generations can be met on the basis of renewable resources. But, making full use of the potential offered by renewable resources can be hindered by market and political conditions, as well as cost and cost (Owusu, P.A., \& Asumadu-Sarkodie, S., 2016).

At the level of local communities, due to the possibilities of producing renewable energy, electricity consumers have an important role in the use of renewable energy sources (EC, 2015).

The analysis shows that renewable energy sources are increasingly used and at European level the proposals for the coming years are very ambitious.

And in the field of transport, measures can be implemented to reduce total energy consumption in transport as well as increase energy efficiency of transport. These include increasing the share of electric cars and transport planning (EP, 2009). Measures leading to the implementation of low-carbon technologies or even technologies leading to the removal of carbon dioxide from the atmosphere are necessary (IPCC, 2014).

It is believed that in the coming years the proportion of electricity in the final energy demand will increase, so that in 2050 it will reach 53\%. At the same time, in 2050, renewable energy sources will account for almost $80 \%$ of electricity (EC, 2018).

\section{References}

Bran, F., Alpopi, C., \& Burlacu, S. (2018). Territorial Development-Disparities between the Developed and the least Developed Areas of Romania. LUMEN Proceedings, 6(1), 146-155.

Burlacu, S., Gutu, C., \& Matei, F. O. (2018). Globalization-pros and cons. Calitatea, 19(S1), 122-125.

Burlacu, S., Profiroiu, A., \& Vasilache, P. C. (2019). Impact of Demography on the Public Finance of the European Union. Calitatea, 20(S2), 136-138.

Ćetković, S., \& Buzogány, A., (2016). Varieties of capitalism and clean energy transitions in the European Union: When renewable energy hits different economic logics. Climate Policy, 16(5)

European Commission (2011). Communication from the Commission to the European Parliament, the Council, the European Economic and Social Committee and the Committee of the Regions - Energy Roadmap 2050

European Commission (2015). Communication to the European Parliament, the Council, the European Economic and Social Committee and the Committee of the Regions. Closing the loop - An EU action plan for the Circular Economy. COM/2015/614.

European Commission (2018). Communication to the European Parliament, the European Council, the Council, the European Economic and Social Committee, the Committee of the Regions and the European Investment Bank - A Clean Planet for all. A European strategic long-term vision for a prosperous, modern, competitive and climate neutral economy

European Parliament (2009). Directive 2009/28/EC of the European Parliament and of the Council of 23 April 2009 on the promotion of the use of energy from renewable sources and amending and subsequently repealing Directives 2001/77/EC and 2003/30/EC

European Parliament (2018). MEPs set ambitious targets for cleaner, more efficient energy use 
Intergovernmental Panel on Climate Change (2014). Climate Change 2014 Synthesis Report - Summary for Policymakers

Ionita, F., Ursacescu, M., \& Burlacu, S. (2009). Public services as poles of regional competitiveness in sustainable development. Revista de Management Comparat International/Review of International Comparative Management, 10(3), 552-565.

Litra, M., \& Burlacu, S. (2014). Management regulatory liberalization of the public service contracts in the rail industry. Administratie si Management Public, (22), 73.

Owusu, P.A. and Asumadu-Sarkodie, S., (2016). A review of renewable energy sources, sustainability issues and climate change mitigation. Cogent Engineering, 3(1)

Paltsev, S., (2016). The complicated geopolitics of renewable energy. Bulletin of the Atomic Scientists, 72(6)

Panwar, N.L., Kaushik, S.C., \& Kothari, S. (2011). Role of renewable energy sources in environmental protection: A review. Renewable and Sustainable Energy Reviews, 15(3)

Rezec, M., \& Bert Scholtens, B., (2017). Financing energy transformation: The role of renewable energy equity indices. International Journal of Green Energy, 14(4)

Su, M.-C., Kao, N.-H. \& Huang, W.-J. (2012). Potential assessment of establishing a renewable energy plant in a rural agricultural area. Journal of the Air \& Waste Management Association, 62(6)

United Nations Environment Programme (2011). Renewable energy: Investing in energy and resource efficiency.

United Nations Framework Convention on Climate Change (2015). Adoption of the Paris agreement 